\title{
THE DISTRIBUTION OF Cd AND CU IN SEDIMENTS COVERED WITH ALGAL MAT
}

\author{
M. LADAKIS* \\ C. BELIAS \\ S. TRIANTAFYLLAKI \\ M. DASSENAKIS \\ M. SCOULLOS
}

Received: 24/04/07

Accepted: 04/06/07
University of Athens, Faculty of Chemistry

Laboratory of Environmental Chemistry

Panepistimioupolis 15771 Athens, Greece

*to whom all correspondence should be addressed: e-mail: eladakis@in.gr

\begin{abstract}
In coastal marine environments, with shallow, warm and calm waters, it is sometimes possible to observe the presence of organosedimentary structures that are commonly flat and laminar in shape. These structures are called algal mats or recent stromatolites due to their remarkable similarities to fossil stromatolites. The aim of this work was the study of the distribution of the various forms of $\mathrm{Cu}$ and $\mathrm{Cd}$ in the main layers of coastal algal mats in a closed bay at Anavissos, on the coast of Saronikos Gulf.

Small sediment cores were collected from one point inside the cove on a seasonal basis and the trace metals extracted according to the BCR sequential extraction method. The main results of the study were:

Most of the labile $\mathrm{Cd}$ was associated with small inorganic grains or lime particles. The contribution of the fraction associated with $\mathrm{Mn}$ and Fe oxides, was similar to that adsorbed to organic compounds and sulfides. The high contribution of the labile $\mathrm{Cd}$ to the total element (over $85 \%$ ) was a strong indication of anthropogenic origin.

On the other hand, most of the $\mathrm{Cu}$ in the sediment was associated with the crystal lattice (74\%). Cu showed increased seasonal fluctuation; most of its labile forms were associated with organic compounds and sulfides whereas the less abundant form was that associated with $\mathrm{Mn}$ and Fe oxides.

On the whole, the sediments were slightly enriched in $\mathrm{Cd}$, while the concentrations of $\mathrm{Cu}$ were normal for the region.
\end{abstract}

KEYWORDS: Anavissos, cadmium, copper, organosedimentary, cyanobacterial mat, recent stromatolites, Saronikos Gulf.

\section{INTRODUCTION}

In coastal marine environments, with shallow, warm and calm waters, it is sometimes possible to observe the presence of organosedimentary structures, which are produced by sediment trapping, binding and/or precipitation as a result of the growth and metabolic activity of microorganisms, principally cyanobacteria. These structures are called microbial, cyanobacterial or algal mats and one of their typical properties is their laminated structure in which different functional groups of microorganisms occur in vertically stratified layers. This type of lamination can be attributed to different growth periods, seasonal events, periodical events (e.g. tides), and episodic or erratic events (e.g. storms) (Brock, 1976; Golubic, 1976; 1983; Stal, 2000). 
Calcification is the general process of consolidation and preservation of microbial mats. Laminated rocks dating from the Precambrian or later eras are known as stromatolites (Krumbein, 1983). Still living well-laminated and consolidated stromatolites can be found in the Bahamas (Exuma Cays), as well as in Australia (Sharks' Bay) (Reid and Brown, 1991). Nowadays algal mats have remarkable similarities with fossil stromatolites and are often characterised as recent stromatolites. However, the most important difference between recent and fossil stromatolites is that the great majority of recent stromatolites do not form consolidated rocks.

These structures have been observed in various Greek coastal areas. The most important of these are mainly located in the peninsula of Attika (Anavissos and Rafina), in eastern Crete and on the island of Lesvos (east Aegean Sea).

The aim of this work was the study of the distribution of various forms of $\mathrm{Cd}$ and $\mathrm{Cu}$ in the main layers of coastal algal mats in a characteristic Mediterranean area. The area of Anavissos was selected for this study due to its ideal conditions for the development of such formations. $\mathrm{Cd}$ and $\mathrm{Cu}$ are environmentally significant metals, widely affected by anthropogenic inputs (Dassenakis et al., 2003). Cd is classified as a dangerous pollutant and a monitoring priority in the Mediterranean region. On the other hand, $\mathrm{Cu}$ is a biologically important metal but is also used in antifouling and pesticide products. High concentrations of this metal in the marine environment may be dangerous to ecosystems.

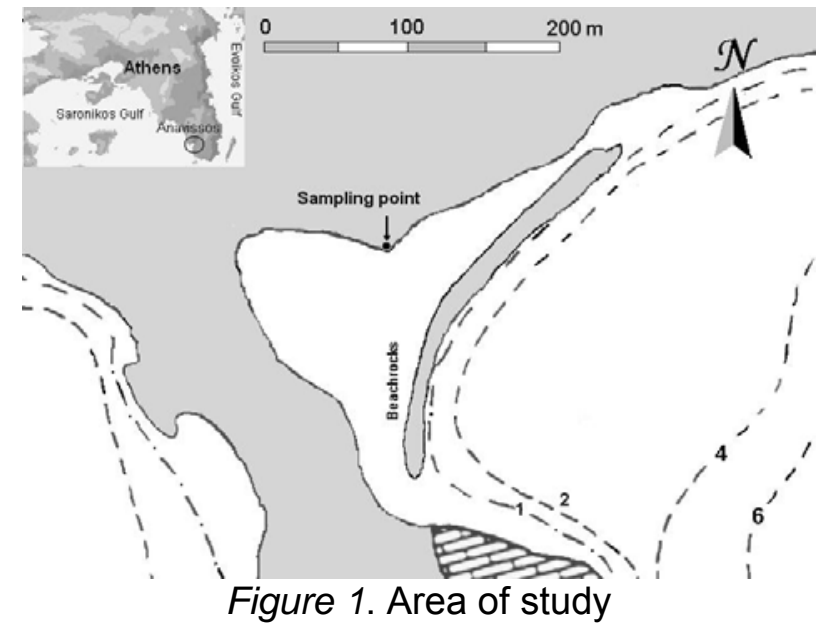

The area under research is a closed bay at Anavissos on the coast of Saronikos Gulf, $50 \mathrm{Km}$ away from Athens, covering an area of about 20,000 square meters (figure 1). A line of beach rocks shuts the bay's entrance, obstructing water renewal. A remarkable reciprocation of the cove's waters due to the wind is also recorded. Throughout the shallow bottom of the cove (max. depth of about 0.6 meters), a layer of green algae with a thickness of $0.2-2 \mathrm{~mm}$ is observed (Krumbein, 1983; Reid and Brown, 1991).

There is an occasional high inflow of fresh water into the cove, usually after heavy rainfalls. No significant pollutant point sources exist in the area but diffused pollution is possible because: (a) during the last few years, many holiday homes have been built in the nearby hills that surround the area. The use of septic tanks (of the cesspool type), in combination with the fact that the groundwater level is very close to sea level, create conditions that favour the contamination of the nearby marine area with urban sewage; (b) refuse is observed all around the area and sometimes in the sea; (c) a number of small recreation and fishing boats use the cove as a safe and free anchorage and their wastes may seriously affect the ecosystem.

\section{MATERIALS AND METHODS}

\section{Sampling and sample treatment}

Sediment cores of about $10 \mathrm{~cm}$ long were collected from one point inside the bay that is partly covered with seawater. Samplings were carried out seasonally from July 2000 to June 2001. The cores were separated into three layers according to their structure (Figure 2):

(a) The upper layer is $0.5-1.2 \mathrm{~mm}$ wide and includes the cyanobacterial mat; 
(b) The middle layer is up to $5 \mathrm{~cm}$ wide, dark in colour, anoxic and has the characteristic odour of hydrogen sulphide;

(c) The lower layer is about $5 \mathrm{~cm}$ wide, brown in colour and represents the background sediment.

The separated layers were freeze-dried, sieved through $0.25 \mathrm{~mm}$ sieves and stored in plastic bottles.

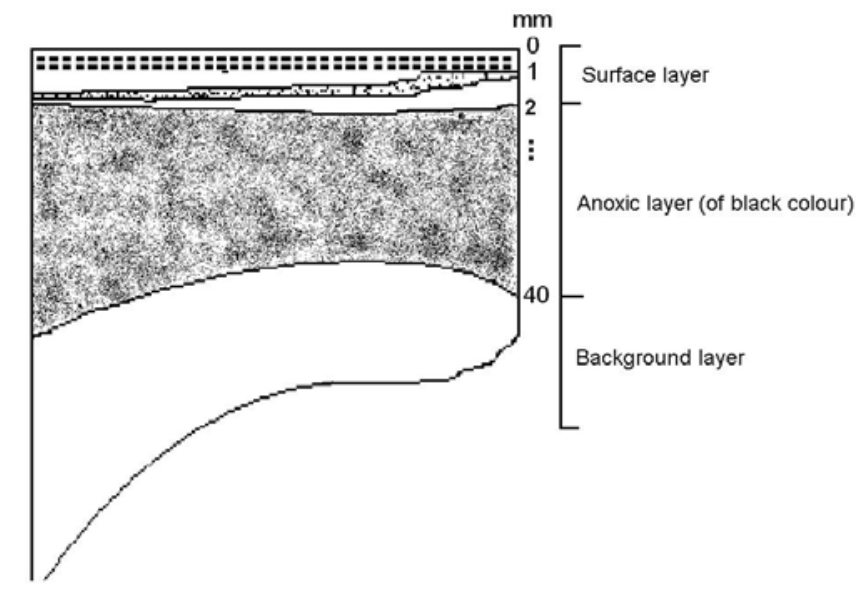

Figure 2. Structure of the algal mat

\section{Sequential extraction procedure}

A slight modification of the BCR sequential extraction procedure was performed in sediment samples (Quevauviller et al., 1997; Rauget et al., 2000). It was chosen because the mobility of trace metals, as well as their bioavailability and related eco-toxicity, depends strongly on their specific chemical forms or ways of binding. Consequently, these have to be determined rather than the total element content in order to assess the toxic effects and study geochemical pathways. According to this procedure, the trace metals are separated into four fractions:

- Fraction A: Metals connected to small inorganic particles and carbonates;

- Fraction B: Metals connected to oxides/hydroxides of Mn and Fe;

- Fraction C: Metals connected to organic compounds and sulphides;

- Fraction D: Metals strongly bound in the alumino-silicate lattice.

Briefly, the sequential extraction procedure applied was as follows:

- Step 1 - Fraction A: About $1 \mathrm{~g}$ of the sediment sample was shaken with $40 \mathrm{ml} \mathrm{CH}_{3} \mathrm{COOH}$ $0.11 \mathrm{M}$ for 16 hours at room temperature.

- Step 2 - Fraction B: The residual of step 1 was shaken for 16 hours with $40 \mathrm{ml}$ $\mathrm{NH}_{2} \mathrm{OH} \cdot \mathrm{HCl} 0.5 \mathrm{M}$ at $\mathrm{pH} 2$ at room temperature.

- Step 3 - Fraction C: The residual of step 2 was treated with $10 \mathrm{ml} \mathrm{H}_{2} \mathrm{O}_{2} 30 \%$ at $85{ }^{\circ} \mathrm{C}$ until the solution volume was reduced to $1 \mathrm{ml}$. Then $50 \mathrm{ml} \mathrm{CH}_{3} \mathrm{COONH}_{4} 1 \mathrm{M}$ (at pH 2) were added and the solution was shaken for 16 hours at room temperature.

- Step 4 - Fraction D: The residual of step 3 was treated with a mixture of strong acids (HF, $\mathrm{HNO}_{3}, \mathrm{HClO}_{4}$ ) at $120^{\circ} \mathrm{C}$ to total dissolution (Thompson and Walsh, 1983; UNEP, 1985).

A reference sediment (CRM-601) was treated by this method. The results are presented in Table 1.

\section{Apparatus}

A Flame Atomic Absorption apparatus (Varian Spectra AA-200) equipped with Sample Introduction Pump System and $D_{2}$ lamp for the background signal correction was used for the determination of $\mathrm{Cu}$. A Graphite Furnace Atomic Absorption apparatus (Varian Spectra AA$640 Z$ GTA 100) equipped with Zeeman background correction system was used for the determination of $\mathrm{Cd}$. 
Table 1. Recovery of the metals in the CRM-601 reference sediment using the BCR sequential extraction method (values in $\mathrm{mg} \mathrm{kg}^{-1}$ )

\begin{tabular}{ccccc}
\hline \multirow{2}{*}{ Metal } & \multicolumn{2}{c}{ Fraction A } & \multicolumn{2}{c}{ Fraction B } \\
& Certified value & Value found & Certified value & Value found \\
\hline $\mathrm{Cd}$ & 4.14 & 3.88 & 3.08 & 2.65 \\
$\mathrm{Cu}$ & 8.32 & 10.2 & 5.69 & 5.25 \\
\hline \hline \multirow{2}{*}{ Metal } & \multicolumn{2}{c}{ Fraction C } & \multicolumn{2}{c}{ Fraction D } \\
& Certified value & Value found & Certified value & Value found \\
\hline $\mathrm{Cd}$ & 1.83 & 1.37 & 1.30 & 1.06 \\
$\mathrm{Cu}$ & 116 & 117 & 60.4 & 48.5 \\
\hline
\end{tabular}

\section{RESULTS AND DISCUSSION}

The mean percentages of the various fractions of $\mathrm{Cd}$ and $\mathrm{Cu}$ for all samplings are presented in Table 2.

The annual mean percentages of the various fractions of $\mathrm{Cd}$ and $\mathrm{Cu}$ in the surface, anoxic and background layer of the sediment are presented in Figure 3.

The labile forms of $\mathrm{Cd}$ are about $85 \%$ of the total metal content indicating that this metal is mostly originating from pollution sources.

Fraction $\mathrm{A}$ (i.e the $\mathrm{Cd}$ associated with small inorganic grains and carbonates) contains most of the labile $\mathrm{Cd}$ (defined as the sum of fractions $A, B$ and $C$ ). The content of the sediment in fraction $A$ is similar within layers, as the annual mean values for the surface, anoxic and background layer are $0.600 \mathrm{mg} \mathrm{kg}^{-1}, 0.624 \mathrm{mg} \mathrm{kg}^{-1}$ and $0.593 \mathrm{mg} \mathrm{kg}^{-1}$ respectively (Figure 4). This behaviour is attributed to the elevated lability of $\mathrm{Cd}$ and to the fact that this metal is not involved in biochemical procedures and therefore can easily be dispersed via the pore water to the various layers of the sediment in a considerable depth.

Table 2. Percentages (over total) of $\mathrm{Cd}$ and $\mathrm{Cu}$ fractions in the various sediment layers Cd

\begin{tabular}{ccccccc}
\hline Layer & Season & $\begin{array}{c}\text { Fraction A } \\
(\%)\end{array}$ & $\begin{array}{c}\text { Fraction B } \\
(\%)\end{array}$ & $\begin{array}{c}\text { Fraction C } \\
(\%)\end{array}$ & $\begin{array}{c}\text { Fraction D } \\
(\%)\end{array}$ & $\begin{array}{c}\text { Total } \\
\left(\mathrm{mg} \mathrm{kg}^{-1}\right)\end{array}$ \\
\hline \multirow{5}{*}{ Surface } & Sum 2000 & 8 & 38 & 34 & 20 & 1.230 \\
& Aut 2000 & 38 & 18 & 28 & 16 & 0.430 \\
& Win 2001 & 45 & 19 & 17 & 19 & 0.961 \\
& Spr 2001 & 79 & 5 & 10 & 6 & 2.170 \\
\hline \multirow{5}{*}{ Anoxic } & Sum 2000 & 45 & 14 & 22 & 19 & 0.266 \\
& Aut 2000 & 39 & 25 & 20 & 15 & 0.335 \\
& Win 2001 & 51 & 22 & 10 & 17 & 0.463 \\
& Spr 2001 & 87 & 4 & 4 & 6 & 2.310 \\
\hline \multirow{2}{*}{ Background } & Sum 2000 & 51 & 11 & 19 & 18 & 0.691 \\
& Win 2001 & 60 & 14 & 17 & 10 & 1.390 \\
\hline
\end{tabular}

$\mathrm{Cu}$

\begin{tabular}{ccccccc}
\hline Layer & Season & $\begin{array}{c}\text { Fraction A } \\
(\%)\end{array}$ & $\begin{array}{c}\text { Fraction B } \\
(\%)\end{array}$ & $\begin{array}{c}\text { Fraction C } \\
(\%)\end{array}$ & $\begin{array}{c}\text { Fraction D } \\
(\%)\end{array}$ & $\begin{array}{c}\text { Total } \\
\left(\mathrm{mg} \mathrm{kg}^{-1}\right)\end{array}$ \\
\hline \multirow{5}{*}{ Surface } & Sum 2000 & 3 & 1 & 13 & 84 & 9.14 \\
& Aut 2000 & 5 & 2 & 35 & 58 & 8.26 \\
& Win 2001 & 5 & 1 & 22 & 72 & 6.07 \\
& Spr 2001 & 4 & $<0.5$ & 19 & 77 & 7.66 \\
\multirow{4}{*}{ Anoxic } & Sum 2000 & 3 & 1 & 37 & 59 & 6.52 \\
& Aut 2000 & 5 & 1 & 40 & 54 & 6.35 \\
& Win 2001 & 6 & 1 & 21 & 73 & 6.08 \\
& Spr 2001 & 6 & 1 & 24 & 69 & 3.41 \\
\hline \multirow{2}{*}{ Background } & Sum 2000 & 4 & 1 & 29 & 67 & 6.03 \\
& Win 2001 & 1 & 0.5 & 2 & 97 & 9.05 \\
\hline
\end{tabular}




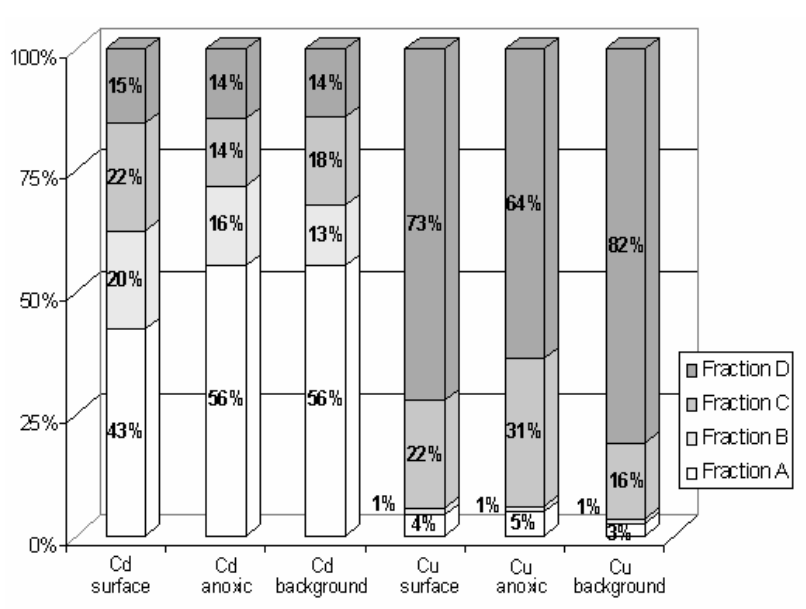

Figure 3. The mean annual percentage distribution of $\mathrm{Cd}$ and $\mathrm{Cu}$ fractions in the various sediment layers

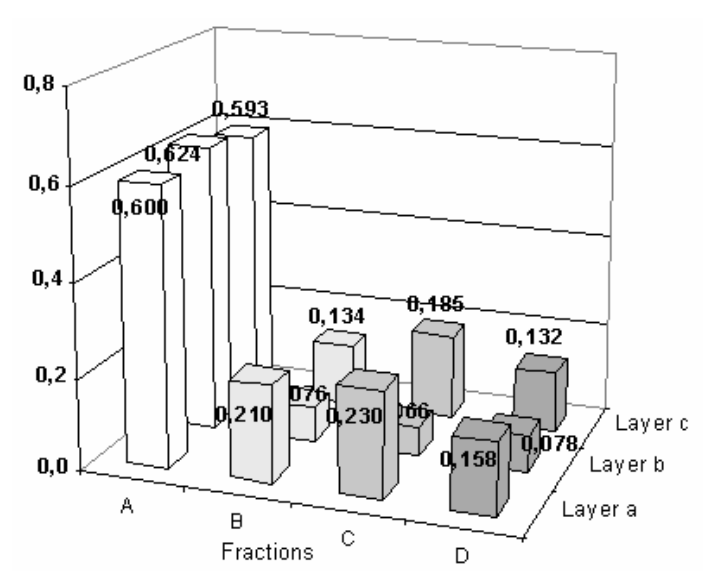

Figure 4. The distribution of $\mathrm{Cd}$ within the sediment's layers (values in $\mathrm{mg} \mathrm{kg}^{-1}$ )

The content of the labile forms of $\mathrm{Cd}$ in the sediment's surface layer has a similar seasonal fluctuation with the concentration of $\mathrm{Cd}$ in the water column as presented in Figure 5 (Ladakis et al., 2007). This indicates the influence of the water column on the surface sediment for the specific metal.

There are also no remarkable differences in the \% contribution of Cd's B and C fractions in each layer (see table 2). The seasonal fluctuation of the sediment's content in Cd shows a remarkable increase of fraction $A$ during spring and a slight increase of fraction $B$ during winter in both surface and anoxic layers. The seasonal fluctuation of fraction $C$ is relatively random.

With the exception of fraction A, the anoxic layer of the sediment contains less Cd than the surface and background layers.

No correlation was detected between the seasonal fluctuation of $\mathrm{Cd}$ and organic matter (Total Organic Carbon - TOC or carbohydrates - TCHO) in the sediment.

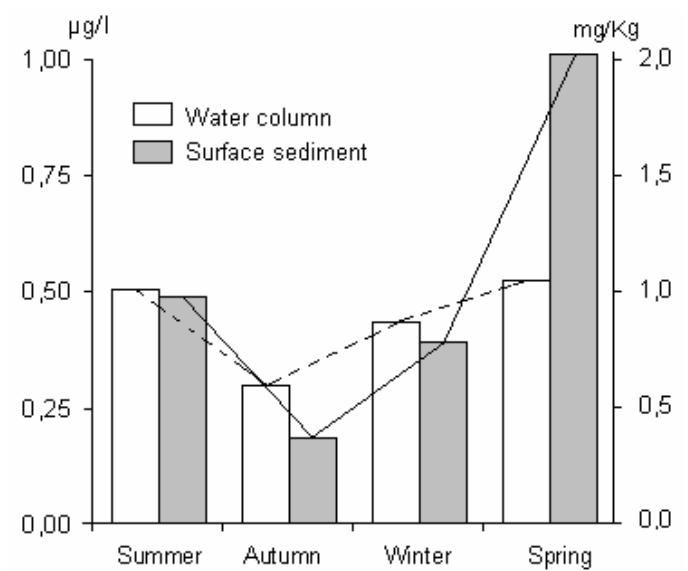

Figure 5. The seasonal fluctuation of $\mathrm{Cd}$ in the water column (values in $\mu \mathrm{g} \mathrm{I}^{-1}$ ) and the surface sediment (values in $\mathrm{mg} \mathrm{kg}^{-1}$ - labile forms only)

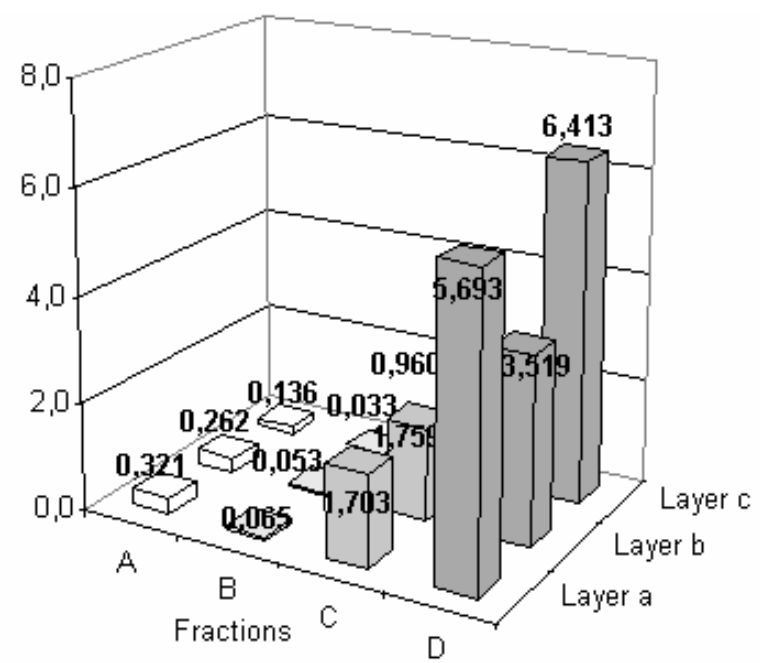

Figure 6. The distribution of $\mathrm{Cu}$ within the sediment's layers (values in $\mathrm{mg} \mathrm{kg}^{-1}$ )

Most of the $\mathrm{Cu}$ in the sediment is associated with the crystal lattice (fraction D) (Table 2 and Figure 3). Considering the biological importance of $\mathrm{Cu}$, we conclude that the elevated 
contribution of Cu's fraction D to the background layer, is attributed to the absence of biological activities in this layer, a fact that does not encourage its enrichment with the labile forms of this metal.

The most abundant labile form of $\mathrm{Cu}$ is the fraction associated with organic compounds and sulphides (fraction $\mathrm{C}$ ), as is apparent form Figures 3 and 6 . This distribution is in accordance with the well-known tendency of $\mathrm{Cu}$ to be bound to organic matter (Breault et al., 1996; Salomons and Forstner, 1984). On the other hand, the lowest values were recorded in fraction $\mathrm{B}$ ( $\mathrm{Cu}$ adsorbed to oxides of $\mathrm{Mn}$ and $\mathrm{Fe}$ ). The vertical distribution of the labile forms of $\mathrm{Cu}$ in the sediment shows a decrease with depth. Specifically, the concentrations of the labile forms of $\mathrm{Cu}$ in the surface and anoxic layers of the sediment are about the same, whilst twice as much is contained in the background layer (Figure 6).

This distribution explains the low values of Cu's fraction B. Most of the labile forms of $\mathrm{Cu}$ accumulate in the surface and anoxic layers of the sediment that are rich in organic compounds and sulphides; most of the $\mathrm{Cu}$ is adsorbed on those compounds resulting in the depletion of $\mathrm{Cu}$ in fraction $\mathrm{B}$.

With regard to the seasonal fluctuation of the labile forms of $\mathrm{Cu}$, the highest values were recorded during autumn both in the surface and anoxic layer of the sediment (Figure 7). The increased values of Total Organic Carbon $(3.7 \% \mathrm{w} / \mathrm{w})$ and Carbohydrates in the sediment during the same period, is the probable reason for this fluctuation (Ladakis et al., 2006). On the other hand, no correlation was detected between the concentration of $\mathrm{Cu}$ in the water column and the content of the labile forms of the same metal in the surface layer of the sediment.

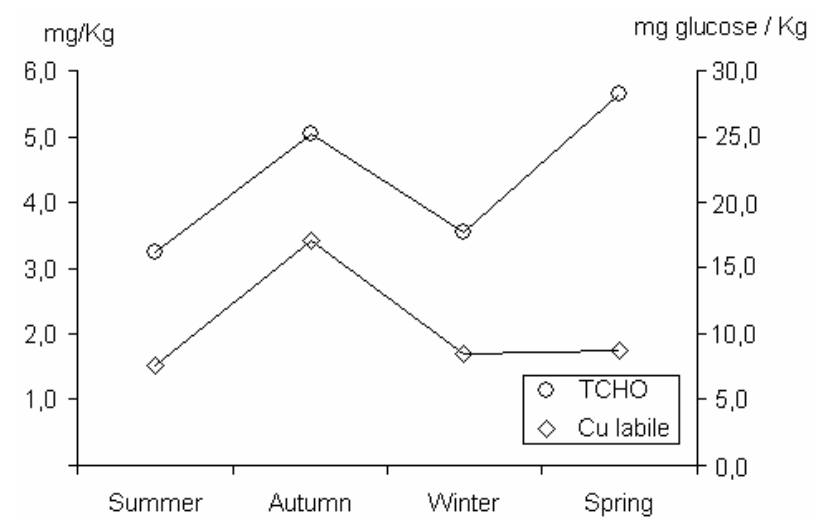

Figure 7. The seasonal distribution of the labile forms of $\mathrm{Cu}$ (left axis) and total carbohydrates (right axis) in the surface layer (values in $\mathrm{mg} \mathrm{kg}^{-1}$ )

The mean concentrations of the total $\mathrm{Cd}$ and $\mathrm{Cu}$ in sediments of some areas of Saronikos gulf are presented in Table 3. According to this table, the content of the sediments under study in $\mathrm{Cu}$ is lower compared to the sediments of the open Saronikos gulf. On the other hand, $\mathrm{Cd}$ is present in higher levels in comparison to sediments of polluted areas such as Elefsis bay and the island of Psitalia. These two areas are heavily affected by human activities and are rich in organic mater and metals.

Table 3. Total $\mathrm{Cd}$ and $\mathrm{Cu}$ in sediments of some areas of Saronikos gulf (values in $\mathrm{mg} \mathrm{kg}^{-1}$ )

\begin{tabular}{lcc}
\hline AREA & Cd & Cu \\
\hline Anavissos bay (Zotiadis, 2004) & & 18.0 \\
Offshore Anavissos (Zotiadis, 2004) & $<0.4$ & 10.0 \\
East Saronikos (Zotiadis, 2004) & 0.4 & 19.0 \\
Elefsis bay (Giannopoulou, 2005) & 0.97 & 164 \\
South Psitalia isl. (Giannopoulou, 2005) & 0.81 & 85.0 \\
Studied sediments (Surface) & 1.20 & 7.78 \\
Studied sediments (Anoxic) & 0.84 & 5.59 \\
Studied sediments (Background) & 1.04 & 7.54 \\
\hline
\end{tabular}


Moreover, the surface layer of the sediments originating from Elefsis bay (Sakelari, 2006) have a similar \% distribution in the various fractions of $\mathrm{Cd}$ and $\mathrm{Cu}$ with that recorded in the surface layer of the area under study, as presented in Table 4:

Table 4. Comparison of the \% distribution of $\mathrm{Cd}$ and $\mathrm{Cu}$ in sediments of Elefsis and Anavissos bay

\begin{tabular}{ccccc}
\hline Fractions & \multicolumn{2}{c}{ Cd (\%) } & \multicolumn{2}{c}{ Cu (\%) } \\
& $\begin{array}{c}\text { Elefsis Bay } \\
(2004-5)\end{array}$ & Anavissos & $\begin{array}{c}\text { Elefsis Bay } \\
(2004-5)\end{array}$ & Anavissos \\
\hline A & 33 & 43 & 2 & 4 \\
B & 13 & 20 & $<1$ & 1 \\
C & 7 & 22 & 17 & 22 \\
D & 46 & 15 & 81 & 73 \\
\hline
\end{tabular}

Therefore, this could indicate that in sediments rich in organic matter, the various forms of both $\mathrm{Cd}$ and $\mathrm{Cu}$ show a specific distribution pattern.

The TEL/PEL (Threshold Effect Level / Probable Effect Level, (Long et al., 1998) criteria were applied in order to characterize the contamination level of each layer of the sediment. The results are presented in Table 5.

Table 5. Contamination level of the sediment according to the TEL/PEL criteria

\begin{tabular}{cccc}
\hline Metal & Surface layer & Anoxic layer & Background layer \\
\hline $\mathrm{Cd}$ & Low contaminated & Low contaminated & Low contaminated \\
$\mathrm{Cu}$ & No contaminated & No contaminated & No contaminated \\
\hline
\end{tabular}

\section{CONCLUSIONS}

The existence of the cyanobacterial mat on the surface of the sediment influences the temporal, spatial and fractional distribution of $\mathrm{Cd}$ and $\mathrm{Cu}$, although their distribution is also affected by their biological importance and geological background, as well as human influence. Thus, differences between the fluctuations of these two metals were recorded in all of the distributions mentioned above.

With regard to their seasonal distribution, the highest values for $\mathrm{Cd}$ were recorded during spring and the lowest during autumn, whereas the highest values for $\mathrm{Cu}$ were recorded during summer and the lowest during spring (Table 2).

As regards the vertical distribution of $\mathrm{Cd}$, the anoxic layer is depleted in all fractions of $\mathrm{Cd}$ except fraction A (Figure 4). On the other hand no such behaviour was recorded for $\mathrm{Cu}$.

$\mathrm{Cd}$ is mostly adsorbed in the sediment's small inorganic particles and carbonates (fraction A). Fraction $\mathrm{D}$ of this metal (crystal lattice) does not exceed $20 \%$ indicating that its origin is mostly human. This indication is in accordance with the fact that $\mathrm{Cd}$ is mainly associated with human activities. Also, the increased mobility of this metal is a possible danger to the ecosystem.

$\mathrm{Cu}$, a metal with significant biological importance shows increased seasonal fluctuation, in the surface layer of the sediment. Its main fraction is $D$ and most of its labile forms are associated with organic compounds and sulphides (fraction $\mathrm{C}$ ). The abundance of extra cellular polymeric substances excreted by the cyanobacteria, as well as the high content of the sulphides in the anoxic layer (Stal, 2000), favour the agglomeration of the labile forms of $\mathrm{Cu}$ to this fraction.

The \% fractional distributions of $\mathrm{Cd}$ and $\mathrm{Cu}$ are similar to those prevailing in Elefsis gulf, a marine area of Saronikos gulf, heavily affected by human activities and rich in organic matter and various metals.

Finally, according to the TEL/PEL criteria, we can conclude that the sediments of the studied area are partially contaminated with $\mathrm{Cd}$ but not with $\mathrm{Cu}$. 


\section{REFERENCES}

Breault R., Colman J., Aiken G. and McKnight D. (1996) Copper speciation and binding by organic matter in copper-contaminated streamwater, Environ. Sci. Technol, 30: 3477 - 3486.

Brock T.D., (1976) Environmental microbiology of living stromatolites. In: Walter M.R (ed) Stromatolites, Developments in Sedimentology, Elsevier comp. Amsterdam, Oxford, New York, 20, 141 - 148.

Dassenakis M., Andrianos H., Depiazi G., Konstantas A., Karabela M., Sakelari A. and Skoullos M., (2003) The use of various methods for the study of metal pollution in marine sediments, the case of Euvoikos Gulf, Greece, Applied Geochemistry 18 (2003) 781 - 794.

Giannopoulou K. (2005) Heavy metals in the sediments and the waters of Saronikos gulf for the year 2004, MSc Thesis, University of Athens, $64-70$

Golubic S., (1976) Organisms that build stromatolites. In: Walter, M.R. (ed.) Stromatolites. Developments in Sedimentology, Elsevier comp. Amsterdam, Oxford, New York, 20, 113-127.

Golubic S., (1983) Stromatolites, fossil and recent: a case history. In: P. Wesrbroek and W. de Jong (eds.) Biomineralizarion and Biological Metal Accumulation, Reidel D. Publishing Company, 313-326.

Krumbein W.E., (1983) Stromatolites. The challenge of a term in space and time, Precambrian Res, 20: $493-531$.

Ladakis M., Dassenakis M., Scoullos M. and Belias C. (2006) 'Organic carbon and total carbohydrates in the sediment of a shallow and semi-closed cove with cyanobacteria mat in its bottom, $8^{\text {th }}$ panhellenic symposium of oceanography $4-8$ June 2006, Thessaloniki Greece, Abstract book p. 74.

Ladakis M., Dassenakis M., Scoullos M. and Belias C. (2007) The chemical behaviour of trace metals in a small, enclosed and shallow bay on the coast of Attika, Greece, Desalination 213 (2007) $29-37$.

Long E.R., Field L.J., Mac-Donald D.D. (1998) Predicting toxidity in marine sediments with numerical sediment quality guidelines, Environ. Toxicology and Chemistry, 17 (4), 714 727.

Quevauviller P., Rauget G., Lopez-Sanchez J.F., Rubio R., Ure A. and Muntau H. (1997) The certification of the EDTA-extractable contents (mass fraction) of $\mathrm{Cd}, \mathrm{Cr}, \mathrm{Ni}, \mathrm{Pb}$ and $\mathrm{Zn}$ in sediment following a three-step sequential extraction procedure, Report EUR - 17554 EN.

Rauget G., Lopez-Sanchez J.F., Sahuquillo A., Muntau H. and Quevauviller P. (2000) Indicative values for extractable contents (mass fractions) of $\mathrm{Cd}, \mathrm{Cr}, \mathrm{Cu}, \mathrm{Ni}, \mathrm{Pb}$ and $\mathrm{Zn}$ in sediment (CRM 601) following the modified BCR-sequential extraction (three-step) procedure, Report EUR - 19502 EN.

Reid R.P. and Brown K.M., (1991) Intertidal stromatolites in a fringing Holocene reef complex, Bahamas, Geology, 19: $15-18$.

Sakelari, K. (2006) Biochemical study of metals' cycle in seawater and sediments and their impact in the food chain, PhD thesis, University of Athens pp 169, 182, 187.

Salomons W. and Förstner U., (1984): Metals in the Hydrocycle, pp 28 - 33, Springer-Verlag editions, Berlin, Heidelberg, New York, Tokyo

Stal J.L. (2000) Cyanobacterial mats and stromatolites. In: Whitton B.A and Potts M. (eds) The Ecology of Cyanobacteria. Their Diversity in Space and Time, Kluwel Academic Publishers, Netherlands.

Stal J.L., (2000) Cyanobacterial Mats and Stromatolites. In Whitton B.A. and Potts M. (eds) The Ecology of Cyanobacteria. Their Diversity in Space and Time, Kluwer Academic Publishers, Netherlands, $61-120$.

Thompson M. and Walsh J.N. (eds) (1983) A handbook for inductively Coupled Plasma Spectroscopy, Brockie and Son Ltd, New York.

UNEP (1985) Reference Methods for Marine Pollution Studies, Report no 31 - 39.

Zotiadis B. (2004) Oceanography and geochemistry of the NE Attica, the island of Makronissos and the island of Kea, PhD Thesis, University of Athens, $48-50$ 